\title{
Pathogenicity of Beauveria bassiana and Metarhizium anisopliae to Anastrepha fraterculus (Diptera: Tephritidae) and Effects on Adult Longevity
}

\author{
Sandra M. Chaneiko ${ }^{1}$, Andressa L. de Brida ${ }^{1}$, Pedro G. Bassa ${ }^{1}$, Marco H. F. Telles ${ }^{1}$, Luana A. dos Santos ${ }^{1}$, \\ Daniela I. B. Pereira ${ }^{1}$, Roberto M. Pereira ${ }^{2} \&$ Flávio R. M. Garcia ${ }^{1}$ \\ ${ }^{1}$ Federal University of Pelotas, Pelotas, RS, Brazil \\ ${ }^{2}$ University of Florida, Gainesville, Fl, USA \\ Correspondence: Flávio R. M. Garcia, Institute of Biology, Departament of Ecology, Zoology and Genetics, \\ Federal University of Pelotas, Capão do Leão, RS, Campus Universitário, S/N., Caixa Postal 345, 96010-900 \\ Capão do Leão, RS, Brazil. Tel:53 9933-0017. E-mail: flaviormg@hotmail.com
}

Received: June 15, 2019 Accepted: July 26, 2019 Online Published: September 30, 2019

doi:10.5539/jas.v11n16p132 URL: https://doi.org/10.5539/jas.v11n16p132

\begin{abstract}
Anastrepha fraterculus (Diptera: Tephritidae) is among the most important fruit pests in South America, and the use of entomopathogenic fungi is considered a promising alternative for its control. The objective of this work was to evaluate the pathogenicity of Beauveria bassiana (Balsamo) Vuillemin and Metarhizium anisopliae (Metschnikoff) Sorokin on larvae and pupae of $A$. fraterculus, along with fungal effects on adult fly longevity. Fungal inoculations, fly larvae or pupae were placed in Petri dishes with $1 \mathrm{~mL} /$ plate, and the concentrations of $10,15,20$ and 25 grams of commercial product/liter of water. Controls received water only. To evaluate the residual effect on adult flies, emerging adults were transferred to clean arenas and the adult longevity was monitored. Beauveria bassiana and M. anisopliae caused 93.3 and $96.7 \%$ larval mortality and 14.0 and $15.0 \%$ pupal mortality, respectively. The estimated LC50 and LC90 values were 22.56 and $40.87 \mathrm{~g} / \mathrm{L}$ for B. bassiana, and of 23.45 and $42.02 \mathrm{~g} / \mathrm{L}$ for $M$. anisopliae. Infected adult insects had shorter longevity than non-infected insects, with mean survival of 8.0 and 83.5 days for B. bassiana and M. anisopliae, respectively.
\end{abstract}

Keywords: biological control, biological insecticides, mycoinseticides, fruit fly

\section{Introduction}

The fruit fly Anastrepha fraterculus (Wiedemann 1830) (Diptera: Tephritidae) is among the most important fruit fly pests in South America, infesting more than 100 species of both native and exotic plants (Hendrichs, Vera, De Meyer, \& Clarke, 2015; Zucchi, 2017). The fly damage can both direct, by the female during oviposition and larval development in the fruit, and indirect, due to penetration of secondary pathogens through oviposition injuries (Zart, Fernandes, \& Botton, 2010). Among the fruit fly control techniques, the use of chemical insecticides is the most frequent, however, due to high toxicity these products are less desirable, long no-entry periods and low selectivity toward natural enemies (Garcia, Brida, Martins, Abeijon, \& Lutinski, 2017).

An alternative control for these pests is the use of biological organisms which are efficient, have low environmental impacts and can be combined with other control techniques in an Integrated Pest Management Program (Lenteren, Bolckmans, Kohl, Ravensberg, \& Urbaneja, 2017).

Entomopathogenic fungi stand out as a control alternative due to easy application, efficient pest control in the short time, and safety toward man and the environment (Sinha, Choudhary, \& Kumari, 2016). Among the most commonly used fungi in pest control are Beauveria bassiana (Balsamo) Vuillemin and Metarhizium anisopliae (Metschnikoff) Sorokin (Ascomycota: Hypocreales) which can affect the different stages of the pest development (Butt, Coates, Dubovskiy, \& Ratcliffe, 2016).

When in contact with the host, the fungal spores adhere to the surface of the cuticle, germinate and produce specialized structures (appressoria) that allow penetration of the integument through a combination of enzymes and mechanical forces (Ortiz-Urquiza \& Keyhani, 2013). After penetration, fungal hyphae invade and proliferate in the host hemolymph, leading to insect mortality (Mora, Castilho, \& Fraga, 2016). 
The action of entomopathogenic fungi on Tephritidae fruit flies has been reported for species of economic importance, and fungal efficiency was demonstrated for different phases of the insect's life cycle (Garcia et al., 2017). Metarhizum anisopliae caused $86.0 \%$ mortality in immature stages of Anastrepha fraterculus (Destéfano, Bechara, Messias, \& Piedrabuena, 2005) and B. bassiana caused $85.0 \%$ mortality in Anastrepha ludens (Loew) (Sánchez-Roblero, Huerta-Palacios, Valle, Gómez, \& Toledo, 2012). High pathogenicity was also observed in larvae of Ceratitis capitata (Wied.), where B. bassiana and M. anisopliae had $73.8 \%$ and $96.6 \%$ of mortality (Khlaywi, Khundhair, Alrubeai, Shbar, \& Hadi, 2014). These fungi also caused 100\% mortality of Bactrocera zonata (Saunders) adults at the concentration of $3 \times 10^{8}$ conidia/mL (Gul, Freed, Akmal, \& Malik, 2015). Beauveria bassiana caused $80.0 \%$ mortality in Rhagoletis indifferens (Curran) larvae and $20.0 \%$ in pupae at a dose of $1 \times 10^{8}$ conidia/gram of soil (Cossentine, Thistlewood, Goettel, \& Jaronski, 2010).

In view of the damage that $A$. fraterculus causes to many economically important fruit species and the potential efficiency of entomopathogenic fungi as part of an Integrated Pest Manegement (IPM) approach, the present study aimed to evaluate the pathogenicity of B. bassiana and M. anisopliae on larvae and pupae of $A$. fraterculus and lasting effect on adult longevity.

\section{Method}

Insect populations: The experiments were carried out at the Laboratório de Ecologia de Insetos of the Federal University of Pelotas-UFPel, in the district of Capão do Leão, Rio Grande do Sul, Brazil. The larvae and pupae of A. fraterculus were obtained from the creation of insects from the Laboratory of Insect Biology-UFPel, kept at $25 \pm 1{ }^{\circ} \mathrm{C}$, and $70 \pm 10 \%$ relative humidity with $12 \mathrm{~h}$ photophase. The insects were transferred to Petri dishes (10 $\mathrm{cm}$ in diameter $\mathrm{x} 1.5 \mathrm{~cm}$ in height) containing moist cotton and artificial diet based on refined sugar, wheat germ and beer yeast $(3: 1: 1)$ (Bionis ${ }^{\circledR}$ BIONIS ${ }^{\circledR}$ YE MF and NS), according to the methodology Salles (1992) modified by Nunes et al. (2013).

Fungal isolates: The commercial B. bassiana (BOVERIL ${ }^{\circledR}$ WP PL63) and M. anisopliae (METARRIL $®$ WP E9) wettable powder products were obtained from Koopert Biological Systems. Conidial viability tests were carried out at the Laboratório de Micologia of the Federal University of Pelotas-UFPel, using the microculture technique, adapted from França, Marques, Torres, and Oliveira (2006). The fungal products were diluted to the concentration of $1 \times 10^{4}$ conidia/mL of distilled water in concentration and $100 \mu \mathrm{L}$ of the suspensions were inoculated on potato agar dextrose medium (PDA) in 9-cm Petri dishes. The Petri dishes were incubated at $25 \pm 1{ }^{\circ} \mathrm{C}$, with $70 \pm 10 \% \mathrm{RH}$, in the dark until colony forming units (CFUs) were sufficiently grown to be counted. This procedure was repeated daily for four days for each isolate used.

Pathogenicity and lethal concentration $\left(\mathrm{LC}_{50}\right.$ and $\left.\mathrm{LC}_{90}\right)$ : Experiments were conducted in a complete randomized design with eight treatments and a control, all applied in 10 replicates, using fungal isolates following methodology by F. Q. Oliveira, Batista, Malaquias, Almeida, and R. Oliveira (2010). The commercial products were weighed in aliquots representing the concentrations recommended by the manufacturer for field application $\left(10,15,20\right.$ and 25 grams of product/liter of water or $5.0 \times 10^{6}, 7.5 \times 10^{6}, 10.0 \times 10^{6}$ and $12.5 \times 10^{6}$ conidia $/ \mathrm{mL}$ respectively). Products were transferred to flasks with $1 \mathrm{~L}$ of sterile water and agitated in vortex agitators until complete dilution. From the initial solution, aliquots of $17 \mu \mathrm{L}$ were removed (recommended by the manufacturer) and were diluted in $1 \mathrm{~mL}$ of water (distilled and sterile) and inoculated into Petri dishes $(9 \mathrm{~cm})$ coated with two sterilized sheets of filter paper disks (autoclave at $1 \mathrm{~atm}$ and $121{ }^{\circ} \mathrm{C}$ for 30 minutes). The control consisted of 1 $\mathrm{mL}$ sterile distilled water per container applied in similar manner as the fungal treatments. After inoculation, 10 A. fraterculus larvae and/or pupae were inserted separately in each Petri dishes. Larvae (13-day old), corresponding to the stage in which the larva leaves the fruit towards the soil, and pupae with fully formed integument (1 day after pupation) were used in the experiments. The Petri dishes were sealed with PVC film and stored in incubator $\left(25 \pm 1{ }^{\circ} \mathrm{C}, 70 \pm 10 \% \mathrm{RH}\right.$, and complete darkness). Third instar larva and pupa mortality were evaluated daily until the complete emergence of the control adults (12 to 15 days).

In order to confirm mortality due to fungal infection, dead insects and non-viable pupae were removed from the inoculation Petri dish and were sterilized with sodium hypochlorite (1.0\%), then alcohol $(70.0 \%)$ followed by wash in sterile distilled water (Quesada-Moraga, Martin-Carballo, Garrido-Jurado, \& Santiago-Alvarez, 2008). After asepsis, the insects were incubated in Petri dishes $(9 \mathrm{~cm})$ lined with two sheets of moist sterile filter paper ( $1 \mathrm{ml}$ sterile distilled water). The Petri dishes with the insects were capped and sealed with plastic film and stored in incubator set at $25 \pm 1{ }^{\circ} \mathrm{C}$, RH of $70 \pm 10 \%$, and lights off to allow fungal development on the insect cadaver. 
Sublethal effect on adult insects: The experiment was carried out in a completely randomized design with three treatments and 10 replicates. The $B$. bassiana and $M$. anisopliae strains used previously were prepared in suspensions with $12.5 \times 10^{6}$ conidia/mL, diluted in sterile distilled water and agitated in a vortex agitator to homogenize the solution. Aliquots of $17 \mu \mathrm{L}$ were withdrawn from the initial solution, diluted again in one $\mathrm{mL}$ sterile distilled water and applied to Petri dishes $(9 \mathrm{~cm})$ containing two sheets of sterile filter paper. For the control, $1 \mathrm{~mL}$ of sterile distilled water (without the fungal isolate) was used per replicate (Oliveira et al., 2010).

After the inoculation, the larvae were transferred to Petri dishes, which were sealed with plastic film and stored in an incubator at $25 \pm 1{ }^{\circ} \mathrm{C}$ and $\mathrm{RH} 70 \pm 10 \%$, in the dark until adult emergence. The adults were transferred into transparent plastic cages $(500 \mathrm{~mL})$, that was covered with netting to allow ventilation and gas exchange. The insects were separated according to the treatment, repetition and date of emergence, and kept in an incubator at $25 \pm 1{ }^{\circ} \mathrm{C}$ and $\mathrm{RH} 70 \pm 10 \%$ and $12 \mathrm{~h}$ photophase. The insects were fed an artificial diet containing wheat germ, yeast and sugar (Salles, 1992) adapted by Nunes et al. (2013). Water was provided in moistened hydrophilic cotton placed in a Petri dish $(2 \mathrm{~mL} /$ dish $)$.

Evaluations were performed daily until all adult insects were dead. To confirm death by fungal infection, the dead adults were removed from the cages, sterilized in sodium hypochlorite $(1.0 \%)$, alcohol $(70.0 \%)$ and sterile distilled water, and incubated in Petri dishes with two sheets of sterile filter paper and $1 \mathrm{~mL}$ of sterile distilled water, which were capped and sealed with plastic film, then stored in a dark incubator at a temperature of $25 \pm 1{ }^{\circ} \mathrm{C}$ and $\mathrm{RH} 70 \pm 10 \%$. Petri dishes with the insects remained in the incubator for 20 days or less if they showed symptoms of infection, following methods of Destéfano et al. (2005).

Statistical analyses: Mean mortalities were compared separately for larvae, pupae and adults in each treatment using ANOVA analysis, mean separation with Tukey's test, and a 5\% confidence interval, using the program Sisvar 5.6 (Ferreira, 2011). The $\mathrm{LC}_{50}$ and $\mathrm{LC}_{90}$ values and the respective confidence intervals $(95 \% \mathrm{CI})$ were obtained by Probit analysis using statistical software Statistica 13.0 (Statsoft 2013). To evaluate the effect of treatments on longevity of adult insects, the Kaplan-Meier analysis was performed through SPSS Statistics 22.0 (IBM SPSS Inc 2013) with a 5\% confidence interval.

\section{Results and Discussion}

Both fungal isolates had high conidial viability, with a mean of $86.25 \%$ for $B$. bassiana and $89.75 \%$ for $M$. anisopliae, and germination between the third and the sixth day after inoculation (Figure 1). The B. bassiana (BOVERIL ${ }^{\circledR}$ WP PL63) and M. anisopliae (METARRIL ${ }^{\circledR}$ WP E9) isolates showed high conidial viability and significant mortality of $A$. fraterculus pupae and adults. These results were similar to previous work with insects of the genus Anastrepha, when M. anisopliae caused $98.7 \%$ mortality in A. ludens (Loew) larvae (concentration $4.8 \times 10^{5}$ conidia $/ \mathrm{mL}$ ) (Lezama-Gutiérrez et al., 2000), $86.0 \%$ in A. fraterculus immatures $\left(2.52 \times 10^{10}\right.$ conidia/gram of soil) (Destéfano et al., 2005), and 66.0\% in Anastrepha obliqua (Macquart) adults $\left(1 \times 10^{7}\right.$ conidia/mL) (Osorio-Fajardo \& Canal, 2011).

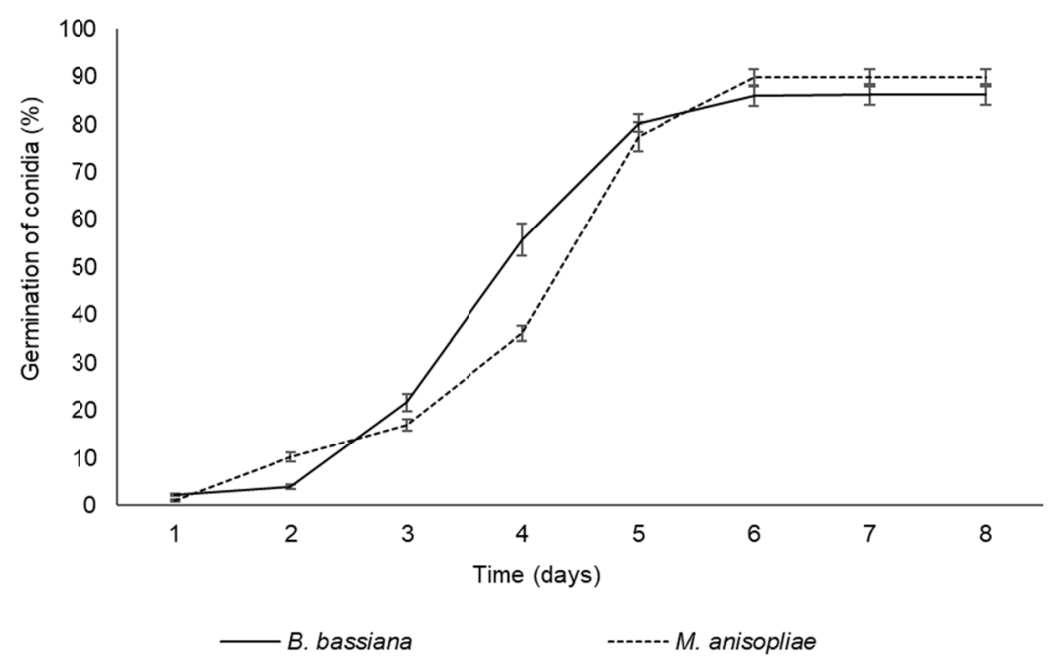

Figure 1. Beauveria bassiana (Balsamo) and Metarhizium anisopliae (Metschnikoff) conidial germination (\%) of over time (days) 
Pathogenicity test: All conidial concentrations of both isolates showed pathogenicity to $A$. fraterculus, with some differences seen as a function of the insect stage of development. In the highest concentration for inoculations to the larval stage, B. bassiana and $M$. anisopliae caused total mortality of up to $93.3 \%( \pm 14.05)$ and $96.7 \%$ $( \pm 14.05)$ of insects, respectively (Table 1). Inoculations at the larval stage resulted in low larval mortality, with $10.0 \%( \pm 16.09)$ for $B$. bassiana and $6.7 \%( \pm 10.50)$ for $M$. anisopliae, which did not differ from the control $(\mathrm{P}=$ 0.600) (Table 1). Despite being infected, the insects advanced to later stages, in which the most mortality occurred. In pupae, B. bassiana caused 56.7\% ( \pm 27.40$)$ and $M$. anisopliae caused 53.3\% ( \pm 23.30$)$ mortality, and both treatments differed from the control (Table 1). In adults, the mortality was $36.7 \%( \pm 18.90)$ with B. bassiana and $43.0 \%( \pm 22.50)$ with $M$. anisopliae, both significantly different from the control (Table 1).

In inoculations carried out at the pupae stage, the higher mortality was $14.0 \%( \pm 6.99)$ with $B$. bassiana, and $15.0 \%( \pm 6.99)$ for $M$. anisopliae. Pupal inoculations did not cause infections to the insects at later stages of development (adult) (Table 2).

Our research tested B. bassiana against third instar larvae of A. fraterculus, and this isolate caused $93.3 \%$ mortality with application of $12.5 \times 10^{6}$ conidia $/ \mathrm{mL}$, which issimilar to the $96.7 \%$ mortality caused by $M$. anisopliae at the same dose. The high efficiency of these entomopathogenic fungi, aided by specific proteases produced during the infection process, which target the proteins in the insect cuticle and facilitate the fungal penetration into the insect body (Sinha et al., 2016). For tephritids, the action of these fungal metabolites was observed in C. capitata (Boudjelida \& Soltani, 2011), with reduction and destruction of the cuticular proteins by M. anisopliae resulting in insect death.

Table 1. Confirmed mortality [mean \pm standard deviation (SD)] in different developmental stages of Anastrepha fraterculus after treatment with fungal isolates Beauveria bassiana (Balsamo) and Metarhizium anisopliae (Metschnikoff) in the larval stage

\begin{tabular}{|c|c|c|c|c|}
\hline $\begin{array}{l}\text { Treatment } \\
\text { Grams/L (Conidia/mL) }\end{array}$ & $\begin{array}{l}\text { Total } \\
\text { (Mort. } \pm \mathrm{SD})\end{array}$ & $\begin{array}{l}\text { Larvae } \\
\text { (Mort. } \pm \text { SD) }\end{array}$ & $\begin{array}{l}\text { Pupae } \\
\text { (Mort. } \pm \text { SD) }\end{array}$ & $\begin{array}{l}\text { Adults } \\
\text { (Mort. } \pm \text { SD) }\end{array}$ \\
\hline \multicolumn{5}{|c|}{ Beauveria bassiana (Balsamo) } \\
\hline $10\left(5.00 \times 10^{6}\right)$ & $50.0 \pm 17.6 \mathrm{~b}$ & $3.3 \pm 10.5 \mathrm{a}$ & $30.0 \pm 10.53 b$ & $16.7 \pm 17.56 b$ \\
\hline $15\left(7.50 \times 10^{6}\right)$ & $63.3 \pm 24.59 b c$ & $6.7 \pm 14.05 \mathrm{a}$ & $33.3 \pm 22.2 b$ & $23.3 \pm 27.43 b$ \\
\hline $20\left(10.00 \times 10^{6}\right)$ & $76.3 \pm 16.10 \mathrm{~cd}$ & $3.0 \pm 10.5 \mathrm{a}$ & $36.6 \pm 10.5 b c$ & $36.7 \pm 18.91 b$ \\
\hline $25\left(12.50 \times 10^{6}\right)$ & $93.3 \pm 14.05 \mathrm{~d}$ & $10.0 \pm 16.09 \mathrm{a}$ & $56.7 \pm 27.4 \mathrm{c}$ & $26.6 \pm 21.07 \mathrm{~b}$ \\
\hline Control & $0.0 \pm 0.00 \mathrm{a}$ & $0.0 \pm 0.00 \mathrm{a}$ & $0.0 \pm 0.00 \mathrm{a}$ & $0.0 \pm 0.00 \mathrm{a}$ \\
\hline $\mathrm{F}(\mathrm{df})$ & $10.27(3)$ & $0.60(3)$ & $3.91(3)$ & $1.49(3)$ \\
\hline Value $\mathrm{P}$ & 0.0001 & 0.619 & 0.0163 & 0.2336 \\
\hline \multicolumn{5}{|c|}{ Metarhizium anisopliae (Metschnikoff) } \\
\hline $10\left(5.00 \times 10^{6}\right)$ & $50.0 \pm 17.56 b$ & $0.0 \pm 0.00 \mathrm{a}$ & $20.0 \pm 17.2 b$ & $30.0 \pm 10.53 b$ \\
\hline $15\left(7.50 \times 10^{6}\right)$ & $86.4 \pm 17.21 \mathrm{c}$ & $0.0 \pm 0.00 \mathrm{a}$ & $43.4 \pm 23.56 b c$ & $43.0 \pm 22.49 b$ \\
\hline $20\left(10.00 \times 10^{6}\right)$ & $56.6 \pm 14.05 b$ & $3.2 \pm 14.05 \mathrm{a}$ & $33.4 \pm 22.2 b c$ & $20.0 \pm 17.2 b$ \\
\hline $25\left(12.50 \times 10^{6}\right)$ & $96.7 \pm 14.05 \mathrm{c}$ & $6.7 \pm 10.5 \mathrm{a}$ & $53.3 \pm 23.3 \mathrm{c}$ & $36.7 \pm 24.5 b$ \\
\hline Control & $0.00 \pm 0.00 \mathrm{a}$ & $0.0 \pm 0.00 \mathrm{a}$ & $0.0 \pm 0.00 \mathrm{a}$ & $0.0 \pm 0.00 \mathrm{a}$ \\
\hline$F(d f)$ & $17.29(3)$ & $1.320(3)$ & $4.409(3)$ & $2.610(3)$ \\
\hline Value $\mathrm{P}$ & 0.0001 & 0.2829 & 0.0097 & 0.0664 \\
\hline
\end{tabular}

Note. The means for the same fungus followed by different letters within the same column are significantly different $(\mathrm{P}<0.05)$. Mort., Mortality; SD, Standard Deviation. 
Table 2. Confirmed mortality [mean \pm standard deviation (SD)] in different developmental stages of Anastrepha fraterculus exposed to treatments with fungal isolates Beauveria bassiana (Balsamo) and Metarhizium anisopliae (Metschnikoff) in the pupal stage

\begin{tabular}{|c|c|c|c|c|}
\hline \multirow{2}{*}{$\begin{array}{l}\text { Treatment } \\
\text { Grams/L (Conídia/mL) }\end{array}$} & \multicolumn{2}{|c|}{ B. bassiana } & \multicolumn{2}{|c|}{ M. anisopliae } \\
\hline & $\begin{array}{l}\text { Pupae } \\
\text { (Mort. } \pm \text { SD) }\end{array}$ & $\begin{array}{l}\text { Adults } \\
(\text { Mort. } \pm \text { SD) }\end{array}$ & $\begin{array}{l}\text { Pupae } \\
\text { (Mort. } \pm \text { SD) }\end{array}$ & $\begin{array}{l}\text { Adults } \\
\text { (Mort. } \pm \text { SD) }\end{array}$ \\
\hline $10\left(5.00 \times 10^{6}\right)$ & $5.0 \pm 5.27 \mathrm{ab}$ & $0.0 \pm 0.00 \mathrm{a}$ & $7.0 \pm 4.83 \mathrm{ab}$ & $0.0 \pm 0.00 \mathrm{a}$ \\
\hline $15\left(7.50 \times 10^{6}\right)$ & $14.0 \pm 6.99 \mathrm{c}$ & $0.0 \pm 0.00 \mathrm{a}$ & $13.0 \pm 6.74 \mathrm{~b}$ & $0 . \pm 0.00 \mathrm{a}$ \\
\hline $20\left(10.00 \times 10^{6}\right)$ & $10.0 \pm 4.71 b c$ & $0.0 \pm 0.00 \mathrm{a}$ & $15.0 \pm 6.99 \mathrm{~b}$ & $0.0 \pm 0.00 \mathrm{a}$ \\
\hline $25\left(12.50 \times 10^{6}\right)$ & $11.0 \pm 5.67 \mathrm{bc}$ & $0.0 \pm 0.00 \mathrm{a}$ & $11.0 \pm 7.37 \mathrm{~b}$ & $0.0 \pm 0.00 \mathrm{a}$ \\
\hline Control & $0.0 \pm 0.00 \mathrm{a}$ & $0.0 \pm 0.00 \mathrm{a}$ & $0.0 \pm 0.00 \mathrm{a}$ & $0.0 \pm 0.00 \mathrm{a}$ \\
\hline $\mathrm{F}(\mathrm{df})$ & $4.271(3)$ & $0.00(0)$ & $2.692(3)$ & $0.00(0)$ \\
\hline Value P & 0.111 & 0.00 & 0.606 & 0.00 \\
\hline
\end{tabular}

Note. The means for the same fungus followed by different letters of the same column are significantly different $(\mathrm{P}<0.05)$. Mort., Mortality; SD, Standard Deviation.

Lethal concentrations $\left(\mathrm{LC}_{50}\right.$ and $\left.\mathrm{LC}_{90}\right)$ : The $\mathrm{LC}_{50}$ and $\mathrm{LC}_{90}$ values for B. bassiana and M. anisiopliae did not differ significantly between the isolates, but there were significant differences between the developmental stages of the insect. After larval inoculations, the insects progressed to the pupal stage, and this stage was affected, with lower $\mathrm{LC}_{50}$ and $\mathrm{LC}_{90}(22.56 \mathrm{~g} / \mathrm{L}$ and $40.87 \mathrm{~g} / \mathrm{L}$ for B. bassiana, and $23.45 \mathrm{gr} / \mathrm{L}$ and $42.02 \mathrm{gr} / \mathrm{L}$ for M. anisopliae, respectively (Table 3). For inoculations at the pupal stage, higher product concentrations were required, with $\mathrm{LC}_{50}$ 's at $95.73 \mathrm{~g} / \mathrm{L}$ and $83.13 \mathrm{~g} / \mathrm{L}$ for B. bassiana and $\mathrm{LC}_{90}$ 's at $175.15 \mathrm{~g} / \mathrm{L}$ and $150.90 \mathrm{~g} / \mathrm{L}$ for M. anisopliae (Table 4).

Table 3. Lethal concentrations $\left(\mathrm{LC}_{50}\right.$ and $\left.\mathrm{LC}_{90}\right)$ (grams/liter) (confidence intervals) of commercial fungal isolates of Beauveria bassiana and Metarhizium anisopliae to larvae, pupae and adults of Anastrepha fraterculus after treatments in the larval stage of the insect

\begin{tabular}{|c|c|c|c|}
\hline & & $\mathrm{LC}_{50} \mathrm{gr} / \mathrm{L}(95 \% \mathrm{FL})$ & $\mathrm{F}(\mathrm{df}) / \mathrm{P}$ \\
\hline \multirow{2}{*}{ Larvae } & B. bassiana & $135.8(105.42-166.29) b$ & $85.6(1.8) / 0.000015$ \\
\hline & M. anisopliae & $122.2(48.04-196.33) \mathrm{b}$ & $11.436(1.8) / 0.009769$ \\
\hline \multirow{2}{*}{ Pupae } & B. bassiana & $22.6(20.80-24.33) \mathrm{a}$ & $248.1(1.8) /<0.001$ \\
\hline & M. anisopliae & $23.5(21.41-25.48) \mathrm{a}$ & $206.3(1.8) /<0.001$ \\
\hline \multirow{3}{*}{ Adults } & B. bassiana & $35.0(31.21-38.70) \mathrm{ab}$ & $193.7(1.8) /<0.001$ \\
\hline & M. anisopliae & $32.5(30.37-34.56) \mathrm{ab}$ & $500.8(1.8) /<0.001$ \\
\hline & & $\mathrm{LC}_{90} \mathrm{gr} / \mathrm{L}(95 \% \mathrm{FL})$ & $\mathrm{F}(\mathrm{df}) / \mathrm{P}$ \\
\hline \multirow{2}{*}{ Larvae } & B. bassiana & $243.2(186.04-300.40) b$ & $85.6(1.8) / 0.000015$ \\
\hline & M. anisopliae & $212.5(76.59-348.11) b$ & $11.4(1.8) / 0.009769$ \\
\hline \multirow{2}{*}{ Pupae } & B. bassiana & $40.9(36.75-45.00) \mathrm{a}$ & $248.1(1.8) /<0.001$ \\
\hline & M. anisopliae & $42.0(37.32-46.72) \mathrm{a}$ & $206.3(1.8) /<0.001$ \\
\hline \multirow{2}{*}{ Adults } & B. bassiana & $63.5(55.25-71.92) \mathrm{ab}$ & $193.7(1.8) /<0.001$ \\
\hline & M. anisopliae & $63.1(57.99-68.27) \mathrm{ab}$ & $500.8(1.8) /<0.001$ \\
\hline
\end{tabular}

Note. The means followed by different letters within the same column are significantly different $(\mathrm{P}<0.05)$. 
Table 4. Lethal concentrations ( $\mathrm{LC}_{50}$ and $\mathrm{LC}_{90}$ ) (grams/liter) (confidence intervals) of commercial fungal isolates of Beauveria bassiana and Metarhizium anisopliae to larvae, pupae and adults of Anastrepha fraterculus after treatments in the pupal stage of the insect

\begin{tabular}{llll}
\hline & & $\mathrm{LC}_{50} \mathrm{gr} / \mathrm{L}(95 \% \mathrm{FL})$ & $\mathrm{F}(\mathrm{df}) / \mathrm{P}$ \\
\hline \multirow{2}{*}{ Pupae } & B. bassiana & $95.7(80.67-110.79) \mathrm{a}$ & $158.9(1.8) / 0.000001$ \\
& M. anisopliae & $83.1(70.56-95.69) \mathrm{a}$ & $163.3(1.8) / 0.000001$ \\
\hline \multirow{2}{*}{ Pupae } & B. bassiana & $\mathrm{LC}_{90} \mathrm{gr} / \mathrm{L}(95 \% \mathrm{FL})$ & $\mathrm{F}(\mathrm{df}) / \mathrm{P}$ \\
& M. anisopliae & $175.1(144.29-202.83) \mathrm{a}$ & $158.3(1.8) / 0.000001$ \\
& $150.9(126.15-175.65) \mathrm{a}$ & $163.3(1.8) / 0.000001$ \\
\hline
\end{tabular}

Note. The means followed by different letters within the same column are significantly different $(\mathrm{P}<0.05)$.

Sublethal effect on adult insects: When inoculated in the larval phase of the insect, B. bassiana and M. anisopliae isolates had effects on adults, reducing their longevity (Figure 2). The mean longevity of adults infected with $B$. bassiana was $8.1( \pm 4.50)$ days and M. anisopliae was $7.80( \pm 4.61)$ days, differing significantly from the control (F: 131.68; df: 2; P: < 0.001). Untreated adults had a longevity of $71.1( \pm 17.79)$ and 75.7 $( \pm 31.81)$ days, which was not significantly different from the control insects, with $83.5( \pm 19.79)$ days (F: 0.68 ; df: 2; P: 0.51) (Figure 2).

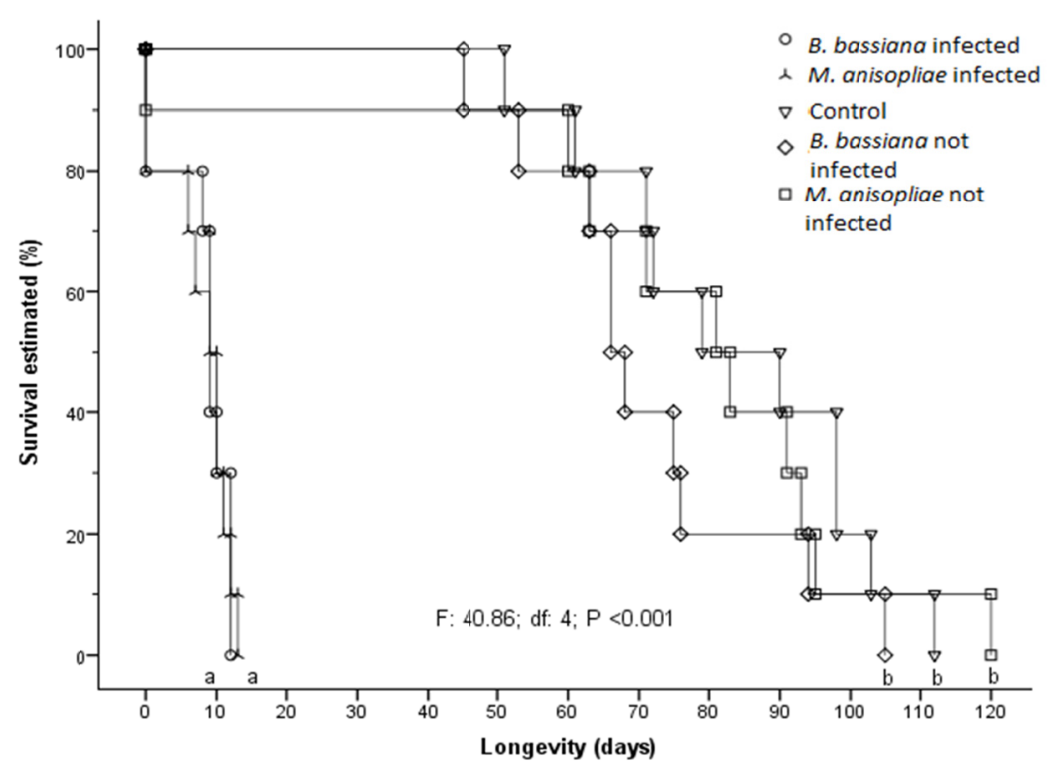

Figure 2. Longevity of adult Anastrepha fraterculus (days) inoculated or not with Beauveria bassiana (Balsamo) or Metarhizium anisopliae (Metschnikoff) during the larval stage. Curves identified by different letters, differ significantly from each other $(\mathrm{P}<0.05)$

The $\mathrm{LC}_{50}$ and $\mathrm{LC}_{90}$ values were more consistent when the fungi were inoculated at the $A$. fraterculus larval stage. The high efficiency of treatments applied to larvae is due to thinner and weaker integument, and the high mobility of the insects which result in greater contact with a larger number of conidia (Cossentine et al., 2010). However, the infected insect is able to pass from the larval to the pupal stage. Because the process of conidia adhesion, germination and tegument penetration lasts about 30 hours, that is sufficient time for the insect to go through the remaining of the larval stage (Mora et al., 2016; Bechara, Destéfano, Bresil, \& Messias, 2011) and pupate. Third instar A. fraterculus larvae infected with M. anisopliae are able to pupate, but the insect dies when the pathogen develops sufficiently during the pupal or adult phase of the insect.

Pupae of $A$. fraterculus showed low susceptibility when exposed to fungal isolates, with only $14.0 \%$ mortality when exposed to B. bassiana $\left(7.5 \times 10^{6}\right.$ conidia $\left./ \mathrm{mL}\right)$ and $15.0 \%$ for M. anisopliae $\left(10.0 \times 10^{6}\right.$ conidia $\left./ \mathrm{mL}\right)$. The reduced mortality is due to sclerosis of the pupal cuticle, which hinders the penetration of the pathogen (Cossentine et al., 2010; Wilson et al., 2017). 
After application to the larval stage, B. bassiana $\left(12.5 \times 10^{6}\right.$ conidia $\left./ \mathrm{mL}\right)$ caused $36.7 \%$ mortality in adult insects and M. anisopliae $\left(7.5 \times 10^{6}\right.$ conidia/mL) caused $43.0 \%$ mortality of adults. These pathogens usually cause host death in the larval or pupal stages, about 24 to 96 hours after conidial adhesion to the insect cuticle (Sinha et al., 2016; Garcia et al., 2017). However, some insects may survive to adulthood even when infected, perhaps due to a strong immune system, which produces antimicrobial peptides and phenoloxidases, or encapsulates the hyphae, reducing or preventing fungal development and the synthesis of toxins (Dubovskiy et al., 2013; Lu \& Leger, 2016). In addition, hemolymph pressure, $\mathrm{pH}$ and temperature in insect hemocele may contribute to delayed pathogen development, resulting in insect mortality only after adult emergence (Meyling \& Eilenberg, 2007; Ortiz-Urquiza \& Keyhani, 2013).

Adult $A$. fraterculus that developed from inoculated pupae did not show fungal growth; however, pupal mortality by pathogen action was observed. The absence of infected adults from pupal inoculations may be due to the rapid kill during the pupal phase due to toxic metabolites secreted by fungi soon after pupal cuticle penetration (Sinha et al., 2016). The sublethal effect of fungi on adult insects from inoculations of immature stages has been reported previously (Bechara et al., 2011; Bissoli, Correia, \& Barbosa, 2014). However, with the present study, we observed $20.0 \%$ mortality on the first day after the adult emergence, reaching $50.0 \%$ mortality by the sixth day, and total mortality by the 12th day. The mortality of adult insects in this period prevents damage to fruits because it occurs before the end of the preoviposition period ( 7 and 14 days after adult emergence) (Zart et al., 2010).

\section{Conclusions}

Beauveria bassiana and M. anisopliae showed high efficiency in the control of A. fraterculus, with lower lethal concentrations $\left(\mathrm{LC}_{50}\right.$ and $\left.\mathrm{LC}_{90}\right)$ in third instar larvae inoculations.

The pathogenicity of $B$. bassiana to A. fraterculus larvae was evaluated for the first time, showing promising effects similar to those by the fungus $M$. anisopliae.

The sublethal effect of these entomopathogenic fungi on adult insects after conidial applications to the larvae reduced adult longevity. Additional field work is needed to verify the efficacy of similar treatments in the field.

\section{References}

Bechara, J. I., Destéfano, R. H. R., Bresil, A. C., \& Messias, C. L. (2011). Histopathological events and detection of Metarhizium anisopliae using specific primers in infected immature stages of the fruit fly Anastrepha fraterculus (Wiedemann, 1830) (Diptera: Tephritidae). Brazilian Journal of Biological, 71, 91-98. https://doi.org/10.1590/S1519-69842011000100014

Bissoli, G., Correia, A. C. B., \& Barbosa, J. C. (2014). Seleção de fungos patogênicos para controle de larvas e pupas da mosca-das-frutas Ceratitis capitata (Diptera: Tephritidae). Cientifica, 43, 338-345. https://doi.org/ 10.15361/1984-5529.2014v42n4p338-345

Boudjelida, H., \& Soltani, N. (2011). Pathogenicity of Metarhizium anisopliae (Metsch) on Ceratitis capitata L. (Diptera: Tephritidae). Annals of Biological Research, 2, 104-110. https://doi.org/10.1590/S1519-566X2006 000300014

Butt, T. M., Coates, C. J., Dubovskiy, I. M., \& Ratcliffe, N. A. (2016). Entomopathogenic Fungi: New Insights into Host-Pathogen Interactions. Advances in Genetics, 94, 307-364. https://doi.org/10.1016/bs.adgen. 2016.01.006

Cossentine, J., Thistlewood, H., Goettel, M., \& Jaronski, S. (2010). Susceptibility of preimaginal western cherry fruit fly, Rhagoletis indifferens (Diptera: Tephritidae) to Beauveria bassiana (Balsamo) Vuillemin Clavicipitaceae (Hypocreales). Journal of Invertebrate Pathology, 104, 105-109. https://doi.org/10.1016/ j.jip.2010.02.006

Destéfano, R. H. R., Bechara, I. J., Messias, C. L., \& Piedrabuena, A. E. (2005). Effectiveness of Metarhizium anisopliae against immature stages of Anastrepha fraterculus fruitfly (Diptera: Tephritidae). Brazilian Journal Microbiolology, 36, 94-99. https://doi.org/10.1590/S1517-83822005000100018

Dubovskiy, I. M., Whitten, M. M. A., Yaroslavtseva, O. N., Greig, C., Kryukov, V. Y., Grizanova, E. V., ... Butt, T. M. (2013). Can insects develop resistance to insect pathogenic fungi? PLoS ONE, 8, 1-9. https://doi.org/10.1371/journal.pone.0060248

Ferreira, D. F. (2011). Sisvar: A computer statistical analysis system. Ciência e Agrotecnologia, 35, 1039-1042. https://doi.org/10.1590/S1413-70542011000600001 
França, I. W. B., Marques, E. J., Torres, J. B., \& Oliveira, J. V. (2006). Efeitos de Metarhizium anisopliae (Metsch.) Sorok. e Beauveria bassiana (Bals.) Vuill. sobre o percevejo predador Podisus nigripisnus (Dallas) (Hemiptera: Pentatomidae). Neotropical Entomology, 35, 349-356. https://doi.org/10.1590/ S1519-566X2006000300009

Garcia, F. R. M., Brida, A. L., Martins, L. N., Abeijon, L. M., \& Lutinski, J. (2017). Biological control of fruit flies of the genus Anastrepha (Diptera: Tephritidae): Current status and perspectives. In D. Lewis (Ed.), Biological control: Methods, applications and challenges. Biological Control of Fruit Flies of the Genus Anastrepha (Diptera: Tephritidae): Current status and perspectives (pp. 26-35). Hauppauge: Nova Science Publishers.

Gul, H. T., Freed, S., Akmal, M., \& Malik, M. N. (2015). Vulnerability of different life stages of Bactrocera zonata (Tephritidae: Diptera) against entomogenous fungi. Pakistan Journal of Zoology, 47, 307-317.

Hendrichs, J., Vera, M. T., De Meyer, M., \& Clarke, A. R. (2015). Resolving cryptic species complexes of major tephritid pests. ZooKeys, 540, 5-39.

IBM SPSS. (2013). SPSS for Windows 22.0. SPSS inc. Chicago, IL.

Khlaywi, S. A., Khundhair, M. W., Alrubeai, H. F., Shbar, A. K., \& Hadi, S. A. (2014). Efficacy of Beauveria bassiana and Metarhizium anisopliae to control mediterranean fruit fly, Ceratitis capitata. International Journal Entomology Research, 2, 169-173.

Lenteren, J. C., Bolckmans, K., Kohl, J., Ravensberg, W. J., \& Urbaneja, A. (2017). Biological control using invertebrates and microorganisms: Plenty of new opportunities. BioControl, 63, 39-59. https://doi.org/ 10.1007/s10526-017-9801-4

Lezama-Gutiérrez, R., Trujillo-De-La-Luz, A., Molina-Ochoa, J., Rebolledo-Dominguez, O., Pescador, A. R., López-Edwards, M., \& Aluja, M. (2000). Virulence of Metarhizium anisopliae (Deuteromycotina: Hyphomycetes) on Anastrepha ludens (Diptera: Tephritidae): Laboratory and field trials. Journal Economic Entomology, 93, 1080-1084. https://doi.org/10.1603/0022-0493-93.4.1080

Lu, H. L., \& Leger, R. J. S. (2016). Insect immunity to entomopathogenic fungi. Advances in Genetics, 94, 251-285. https://doi.org/10.1016/bs.adgen.2015.11.002

Meyling, N. V., \& Andeilenberg, J. (2007). Ecology of the entomopathogenic fungi Beauveria bassiana and Metarhizium anisopliae in temperate agroecosystems: Potential for conservation biological control. Biological Control, 43, 145-155. https://doi.org/10.1016/j.biocontrol.2007.07.007

Mora, M. A. E., Castilho, A. M. C., \& Fraga, M. E. (2016). Fungos entomopatogênicos: Enzimas, toxinas e fatores que afetam a diversidade. Revista Brasileira de Produtos Agropecuários, 18, 335-349.

Nunes, A. M., Costa, K. Z., Faggioni, K. M., Costa, M. L. Z., Gonçalves, R. S., Walder, J. M. M., Garcia, M. S., \& Nava, D. E. (2013). Dietas artificiais para a criação de larvas e adultos da mosca-das-frutas sul-americana. Pesquisa Agropecuária Brasileira, 48, 1309-1314. https://doi.org/10.1590/S0100-204X2013001000001

Oliveira, F. Q., Batista, J. L., Malaquias, J. B., Almeida, D. M., \& Oliveira, R. (2010). Determination of the median lethal Concentration $\left(\mathrm{LC}_{50}\right)$ of mycoinseticides for the controlo of Ceratitis capitata (Diptera: Tephritidae). Revista Colombiana de Entomolologia, 36, 213-216.

Ortiz-Urquiza, A., \& Keyhani, O. N. (2013). Action on the surface: Entomopathogenic fungi versus the insect cuticle. Insect, 4, 357-354. https://doi.org/10.3390/insects4030357

Osorio-Fajardo, A., \& Canal, N. A. (2011). Selection of strains of entomopathogenic fungi for management of Anastrepha obliqua (Macquart, 1835) (Diptera: Tephritidae) in Colombia. Revista Facultad Nacional de Agronomia Medellín, 64, 6129-6139.

Quesada-Moraga, E., Martin-Carballo, I., Garrido-Jurado, I., \& Santiago-Alvarez, C. (2008). Horizontal transmission of Metarhizium anisopliae among laboratory populations of Ceratitis capitata (Wiedemann) (Diptera: Tephritidae). Biological Control, 47, 115-124. https://doi.org/10.1016/j.biocontrol.2008.07.002

Salles, L. A. B. (1992). Metodologia de criação de Anastrepha fraterculus (Wied., 1830) (Diptera: Tephritidae) em dieta artificial em laboratório. Anais da Sociedade Entomologica do Brasil, 21, 479-486.

Sánchez-Roblero, D., Huerta-Palacios, G., Valle, J., Gómez, J., \& Toledo, J. (2012). Effect of Beauveria bassiana on the ovarian development and reproductive potential of Anastrepha ludens (Diptera: Tephritidae). Biocontrol Science Technology, 22, 075-1091. https://doi.org/10.1080/09583157.2012.713090 
Sinha, K. K., Choudhary, A. K., \& Kumari, P. (2016). Entomopathogenic Fungi. In Omkar (Ed.), Ecofriendly pest management for food security (pp. 475-505). Academic Press: London, UK.

Statsoft. (2013). Statistica (data analysis software system) (Version 13). StatSoft Inc., Tulsa, OK.

Toledo, J., Campos, S. E., Flores, S., Liedo, P., Barrera, J. F., Villasenor, A., \& Montoya, P. (2007). Horizontal transmission of Beauveria bassiana in Anastrepha ludens (Diptera: Tephritidae) under laboratory and field cage Conditions. Journal Economic Entomology, 100, 291-297. https://doi.org/10.1603/0022-0493(2007) 100[291:HTOBBI]2.0.CO;2

Wilson, W. M., Ibarra, J. E., Oropeza, A., Hernandez, M. A., Toledo-Hernandez, R. A., \& Toledo, J. (2017). Infection of Anastrepha ludens (Diptera: Tephritidae) adults during emergence from soil treated with Beauveria bassiana under various texture, humidity, and temperature conditions. Florida Entomologist, 100, 503-508. https://doi.org/10.1653/024.100.0302

Zart, M., Fernandes, O. A., \& Botton, M. (2010). Biology and fertility life table of the South American fruit fly Anastrepha fraterculus on grape. Bulletin Insectology, 63, 237-242.

Zucchi, R. A. (2017). Fruit flies in Brazil-Anastrepha species their host plants and parasitoids. Retrieved from http://www.lea.esalq.usp.br/anastrepha

\section{Copyrights}

Copyright for this article is retained by the author(s), with first publication rights granted to the journal.

This is an open-access article distributed under the terms and conditions of the Creative Commons Attribution license (http://creativecommons.org/licenses/by/4.0/). 